\title{
Questes
}

vestes Revue pluridisciplinaire d'études médiévales

6 | 2004

La nuit

\section{Altérités du Moyen Âge, Littérature numéro 130, juin 2003}

Pierre Levron

\section{(2) OpenEdition}

10 Journals

Édition électronique

URL : http://journals.openedition.org/questes/1994

DOI : 10.4000/questes.1994

ISSN : 2109-9472

\section{Éditeur}

Les Amis de Questes

\section{Édition imprimée}

Date de publication : 15 janvier 2004

Pagination : 56-57

ISSN : 2102-7188

\section{Référence électronique}

Pierre Levron, «Altérités du Moyen Âge, Littérature numéro 130, juin 2003 », Questes [En ligne], 6 | 2004 mis en ligne le 01 janvier 2014, consulté le 25 septembre 2020. URL : http://journals.openedition.org/ questes/1994; DOI : https://doi.org/10.4000/questes.1994

Ce document a été généré automatiquement le 25 septembre 2020.

(c) Association des amis de «Questes » 


\section{Altérités du Moyen Âge, Littérature numéro 130, juin 2003}

\section{Pierre Levron}

\section{RÉFÉRENCE}

Littérature, « Altérités du Moyen Âge », n¹30, 2003

NOTE DE L'ÉDITEUR

Cet article n'a pas encore fait l'objet d'une autorisation de publication.

INDEX

Mots-clés : nuit, transition, vision, doctrine

Keywords : night, transition, vision, doctrine 